such processes as equipping production, selling manufactured products, and consuming them. But until we improve the current practice of the accounting system in accordance with modern requirements for making operational management decisions, the full use of accounting capabilities will not be realized quickly. Accounting of agricultural organizations in the Republic of Kazakhstan is carried out in accordance with the general provisions provided for in the International Financial Reporting Standard No. 41 "Agriculture" and the National Financial Reporting Standard No. 1.

"We present this article to students and teachers who are trained in special and higher educational institutions in the specialties "" accounting and audit"", "'Economics"", the main provisions of the rules of accounting in agriculture and methods of accounting, and according to the tax code of the Republic of Kazakhstan special tax regimes are provided for small businesses, peasant (farm) farms, legal entities producing agricultural products, special types of business activities."

Keywords: Accounting, international financial accounting standards, financial accounting, balance sheet.

\title{
МРНТИ 06.52.13
}

ӘОЖ 336.73

https://doi.org/10.51579/1563-2415.2021-4.03

\section{БІРІҢҒАЙ ЖИНАҚТАУШЫ ЗЕЙНЕТАҚЫ ҚОРЫНЫН АКТИВТЕРІН ОРНАЛАСТЫРУДЫН БАЛАМАЛЫ НҰСҚАЛАРЫ}

\author{
Жантаева А. А. \\ Алматы гуманитарль - экономикалық университет, Алматы құласы, Қазақстан \\ e-mail: aigul_0905@mail.ru
}

Түйін. Қазіргі жсаддайда зейнетақы активтерін басқару ерекшелігі, инвестичиялық портфель құрылымына белгілі бір талаптар, явни инвестициялық портфельдегі құралдардың әртүрлі категориялары бойынша жогаргы үлесіне алдын-ала шектеулер қою больп табылады. Олар: активтер бойынша, тәуекелі бойынша, меншіктік шовырлану бойынша, эмитенттер бойынша және баваль қаваздар түрі бойынша. Сондықтан, активтер (акциялар) портфелін қалыптастыру барысында, волатильдігі ең төмен активтер таңдалады, явни бастапқы мақсат болып, активтердің сақталуы, содан кейін табыстылывы болып есептеледі. Бұл тұрвыда инвестициялық портфельді басқару ұйымдары сенімді және өте қысқа мерзімде ақиа құражатына айналатын өтімді қаржы құралдарының құрылымыын қалыптастырып, тәуекелі қолайль деңцгейінде тұрақтыы табыс алуды көздейтін, сонымен бірге бавалы қаваздардыл сатып алмас бұрын, оларды баламалы қаржы құралдарымен мұқият салыстыра отырыл дұрыс шешім құабылдау қุажет. Мұндай стратегияларды қолданудың тимділігі көбінесе инвестичиялық қыызметтің басыңқылыларын (приоритетный) анықтай алуга және мақсаттар мен негізгі қавидаларды құрамдастыра білуге байланысты. Мақсатинвестиииялардың қауіпсіздігін құамтамасыз ету.

Түйінді сөздер: зейнетақы активтері, инвестицияльқ портфель,орташа табыстылық, тәуекелді қауіп, депозитарлық қолхат, еурооблигация, акиия облигация, құрылылмдық ноталар, туынды қаржылық құралдар. 
Негізгі ережелер. Қазіргі кезде экономикадағы интеграциялық процестерге тән ерекшелік, ішкі капитал нарығында инвестициялық ресурстардың жаңа көздерін табу болып табылады. Мұндай ресурстардың бірі, Қазақстанның зейнетақы капиталы нарығында қарқынды өсіп келе жатқан және кез-келген ел мұқтаж, ішкі инвестиция көзі болып табылатын зейнетақы активтері.

Зейнетақы активтерінің куаттылығы (ЖІӨ-нің 11,7 құрайды) мен ұзақтығы (35-40 жыл) жағынан қаржы нарығында тек банктердің меншікті капиталының көлемімен ғана салыстыруға болады (олар инвестицияны 12-15 жылдық мерзімге жоспарлайды) [1].

Зейнетақы активтерін инвестициялау, зейнетақы қорланымының негізгі әдісі болғандықтан, одан түскен табыс міндеттемеге алынған зейнетақы төлемдерін жабуға жеткілікті болуы тиіс. Сонымен бірге, зейнетақы активтерін инвестициялау, зейнетақы қорланымын құнсызданудан сақтаудың бірден-бір жолы болып табылады. Олай болса, зейнетақы қорланымын сақтау және келешек зейнетақыны төлеу міндеттемелерінің орындалуы, инвестицияның нәтижесіне тікелей байланысты.

Кіріспе. Соңғы үш жылда қазақстандық эмитенттердің көпшілігі өздерінің еурооблигацияларымен халықаралық нарыққа шығып отырды. Ең бастысы бұл экономиканы ынталандыру бойынша, мемлекеттік бағдарламалар негізінде әлемдік нарықта қалыптасқан төменгі пайыздық мөлшерлемемен байланысты болған. Мұндай жағдай осы күнге дейін сақталып келеді. Шетелге қаржаттардың бір бөлігін инвестициялау елдік тәуекелді әртараптандыру үшін қажет.

Соңғы жылдары зейнетақы активтерінің құрылымындағы салымдардан, қаржылық құралдардың тек үш түрінің басымдығын байқауға болады (мемлекеттік бағалы қағаздар, банк депозиттері, корпоративтік бағалы қағаздар). Бұл зейнетқы активтері құрылымының әртараптандыру деңгейінің төмен екенін көрсетеді. Жоғарыда аталған шектеулерден кейін зейнетақы активтерінің инвестициялық портфелін тиімді басқару мүмкіндігі жоқтың қасы. Сондықтан осы шектеулерді ескере отырып инвестициялық портфельді басқарудың басқа баламалы жолын қарастыруға болады.

Егер зейнетақы қорланымын инвестициялаудың алуан түрлі нұсқаларын қарастыратын болсақ, онда пайыздық мөлшерлеме деңгейіне, өтімділік деңгейіне және мүмкін болатын тәуекел деңгейіне, сонымен қатар инвестицияға салу мерзімін ескерген маңызды.

Материалдар мен зерттеу әдістері. Сондықтан 1 қаңтар 2021 жылға БЖЗҚ жағдайы бойынша инвестициялық портфельдегі активтерді орналастырудың баламалы нұсқаларын жоғарыдағы қағидаларға сүйене отырып 1- кестеден көрелік.

Kecme 1

Біріңдай жинақтаушы зейнетақы қорының активтерін орналастырудың баламальь нұсқ̧алары

\begin{tabular}{|c|c|c|c|c|c|}
\hline $\begin{array}{c}\text { Қаржылық } \\
\text { құралдардың түрі }\end{array}$ & Мерзімі & $\begin{array}{c}\text { Жылдық } \\
\text { пайыздық } \\
\text { мөлшері }\end{array}$ & Үлесі & $\begin{array}{c}\text { Инвестициялау } \\
\text { сипаттамасы/ } \\
\text { белгілері }\end{array}$ & $\begin{array}{c}\text { Тәуекелді қауіп/ } \\
\text { бағалы қағаз- } \\
\text { дардың рейтин- } \\
\text { гілік бағасы } \\
\end{array}$ \\
\hline 1 & 2 & 3 & 4 & 5 & 6 \\
\hline \multicolumn{3}{|c|}{$\begin{array}{l}\text { Қазақстан Республикасының МБҚ } \\
\text { (инвестициялау шектеуі - 20\% кем емес) }\end{array}$} & & \begin{tabular}{|l|} 
ҚР заңнамасы- \\
мен реттеледі \\
\end{tabular} & \multirow{4}{*}{$\begin{array}{l}\text { Екінші деңгей- } \\
\text { дегі банктердің } \\
\text { кредиттік } \\
\text { рейтинг }\end{array}$} \\
\hline \multirow{3}{*}{$\begin{array}{l}\text { МБҚ орташа } \\
\text { табыстылығы }\end{array}$} & 1 - 4 жыл & жоқ & \multirow{3}{*}{$43,8 \%$} & \multirow{3}{*}{$\begin{array}{l}\text { Екінші нарық } \\
\text { дамымаған }\end{array}$} & \\
\hline & 5 - 7 жыл & $5,9 \%$ & & & \\
\hline & 8-30 жыл & $6,9 \%$ & & & \\
\hline
\end{tabular}


1 - кестенің жалвасы

\begin{tabular}{|c|c|c|c|c|c|}
\hline 1 & 2 & 3 & 4 & 5 & 6 \\
\hline $\begin{array}{l}\text { ҚРҰБ } \\
\text { құрылымдық } \\
\text { ноталары }\end{array}$ & 1 жыл & жоқ & $0,63 \%$ & & \\
\hline \multicolumn{2}{|c|}{$\begin{array}{l}\text { Портфельдегі ҚР МБҚ } \\
\text { бойынша өтеуге шаққандағы, } \\
\text { орташа табыс }\end{array}$} & $8,8 \%$ & & & \\
\hline \multicolumn{3}{|c|}{$\begin{array}{l}\text { Шетелдік эмитенттердің корпоративтік } \\
\text { облигациялары және PPN (құрылымдық } \\
\text { ноталар). } \\
\text { (инвестициялау шектеуі - 24,75\% кем } \\
\text { емес) }\end{array}$} & & \multirow[t]{2}{*}{$\begin{array}{l}\text { Несиелік } \\
\text { сенімділігі } \\
\text { не/немесе } \\
\text { табыстылығы }\end{array}$} & \multirow[t]{2}{*}{$\begin{array}{l}\text { (Fitch) AAA } \\
\text { (Standard } \\
\text { Poor`s) AAA } \\
\text { (Moody`s Inves- } \\
\text { tors Service) Aa1, } \\
\text { Aa3 }\end{array}$} \\
\hline $\begin{array}{l}\text { Шетелдік эми- } \\
\text { тенттердің кор- } \\
\text { поративтік обли- } \\
\text { гациялары } \\
\text { PPN } \\
\text { (құрылымдық } \\
\text { ноталар). }\end{array}$ & $\begin{array}{l}28 \text { жыл } \\
8 \text { жыл } \\
2 \text { жыл }\end{array}$ & $6,25 \%$ & $0,26 \%$ & & \\
\hline \multicolumn{2}{|c|}{$\begin{array}{l}\text { Шетелдік эмитенттердің } \\
\text { корпоративтік } \\
\text { облигациялары бойынша } \\
\text { өтеуге шаққандағы, орташа } \\
\text { табыс }\end{array}$} & $4,38 \%$ & & & \\
\hline \multicolumn{2}{|c|}{$\begin{array}{l}\text { ҚР эмитенттерінің корпора- } \\
\text { тивтік облигациялары } \\
\text { (инвестициялау шектеуі - } \\
30 \% \text { кем емес) }\end{array}$} & $8,51 \%$ & $\begin{array}{l}21,38 \\
\%\end{array}$ & $\begin{array}{l}\text { Эмитенттің } \\
\text { тәуекелдігі , } \\
\text { бағалы } \\
\text { қағаздардың } \\
\text { рейтингілік } \\
\text { бағасы, КР } \\
\text { заңнамасымен } \\
\text { бекітілген } \\
\text { басқа } \\
\text { талаптар }\end{array}$ & $\begin{array}{l}(\mathrm{S} \& \mathrm{P}) \text { BBB-, } \\
\mathrm{BB}, \mathrm{B}+, \mathrm{B}, \mathrm{CCC} \\
\text { (Fitch) B, BB, } \\
\mathrm{BBB}+, \mathrm{CCC}+ \\
\text { (M`s Investors } \\
\text { Service) Ba3, } \\
\text { Caa, } \\
\text { (KZ_S\&P) kzAA- } \\
\text {, kzBB+, kzBBB- } \\
\text { (РФЦA) (PA } \\
\text { РФЦA) BBВ1 } \\
\text { (КZ FITCH) }\end{array}$ \\
\hline \multicolumn{2}{|c|}{$\begin{array}{l}\text { Шет мемлекеттердің МБҚ } \\
\text { Халықаралық қаржылық } \\
\text { ұйымдардың облигациялары } \\
\text { (инвестициялау шектеуі - } \\
\text { 35\% кем емес) }\end{array}$} & $\begin{array}{l}2,13 \% \\
5,83 \%\end{array}$ & $\begin{array}{l}4,22 \% \\
4,13 \%\end{array}$ & $\begin{array}{l}\text { Несиелік } \\
\text { сенімділігі } \\
\text { не/немесе } \\
\text { табыстылық. } \\
\text { Шет } \\
\text { мемлекетінің } \\
\text { дербес } \\
\text { рейтингі }\end{array}$ & $\begin{array}{l}\text { (Moody`s Inves- } \\
\text { tors Service) A3, } \\
\text { B1, B2, Baa2, } \\
\text { (Fitch) AAA } \\
\text { (Standard \& } \\
\text { Poor`s) BBB- } \\
\text { (KZ_STANDAR } \\
\text { D\&POOR'S) } \\
\text { kzBB- }\end{array}$ \\
\hline
\end{tabular}




\begin{tabular}{|c|c|c|c|c|c|}
\hline 1 & 2 & 3 & 4 & 5 & 6 \\
\hline \multicolumn{3}{|c|}{$\begin{array}{l}\text { Портфельдегі шет мемлекеттердің МБҚ } \\
\text { мен ХҚҰ облигацияларын өтеуге } \\
\text { шаққандағы орташа табыстылығы }\end{array}$} & $4,18 \%$ & & \\
\hline \multicolumn{3}{|c|}{$\begin{array}{l}\text { Шетелдік эмитенттердің депозитарлық } \\
\text { қолхаты }\end{array}$} & $0,24 \%$ & & $\begin{array}{l}\text { (Fitch Ratings) } \\
\text { CCC }\end{array}$ \\
\hline $\begin{array}{l}\text { JPMorgan Chase } \\
\text { Bank,USD }\end{array}$ & 2 жыл & $8,12 \%$ & $4,51 \%$ & & \\
\hline \multicolumn{4}{|c|}{$\begin{array}{l}\text { Қазақстан Республикасының ЕДБ депозиттері } \\
\text { (инвестициялау шектеуі - 25\% кем емес) }\end{array}$} & $\begin{array}{l}\text { Табыстылығы } \\
\text { Басқа да да } \\
\text { қаржылық } \\
\text { құралдардың } \\
\text { алдындағы } \\
\text { артықшылығ } \\
\text { ы }\end{array}$ & $\begin{array}{l}\text { (KZ_Fitch) } \\
\text { AA(kaz), BBB+( } \\
\text { kaz) (M`s Inves- } \\
\text { tors Service) } \\
\text { KZ_B1 } \\
(\mathrm{KZ} \text { _S\&P) } \\
(\mathrm{KZ} \text { _FITCH) }\end{array}$ \\
\hline $\begin{array}{l}\text { Тенгедегі } \\
\text { депозиттер }\end{array}$ & \multirow[t]{2}{*}{3 жыл } & $8-10 \%$ & $6,8 \%$ & & \\
\hline $\begin{array}{l}\text { АҚШ } \\
\text { долларындағы де- } \\
\text { позиттер }\end{array}$ & & $5 \%$ & $0,64 \%$ & & \\
\hline \multicolumn{2}{|c|}{$\begin{array}{l}\text { ЕДБ-гі депозиттер бойынша } \\
\text { өтелуге тиісті орташа өлшен- } \\
\text { ген табыстылық }\end{array}$} & $7,74 \%$ & & & \\
\hline \multicolumn{3}{|c|}{ 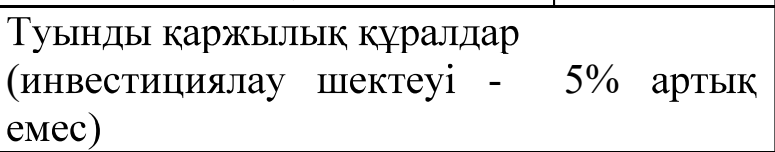 } & \multicolumn{3}{|c|}{$\begin{array}{l}\text { Базалық активке қойылатын талаптар } \\
\text { (қаржылық құралдарды сатып алуға } \\
\text { рұқсат беру) }\end{array}$} \\
\hline \multicolumn{2}{|c|}{$\begin{array}{l}\text { Ақша қаражаты және басқа } \\
\text { да активтер }\end{array}$} & & $3,07 \%$ & & \\
\hline \multicolumn{2}{|c|}{$\begin{array}{l}\text { Зейнетақы активтерінің } \\
\text { барлық инвестициялық } \\
\text { портфелінің өтелуге тиісті } \\
\text { орташа өлшенген } \\
\text { табыстылығы }\end{array}$} & $6,31 \%$ & & & \\
\hline \multicolumn{6}{|c|}{$\begin{array}{l}\text { Ескерту - Дереккөз: enpf.kz } \\
\text { Кұнсыздану - 7,4\%, орташа табыстылық - 6,31\% }\end{array}$} \\
\hline
\end{tabular}

Нәтижесі мен талқылауы. Мемлекеттік облигациялар мерзімділігі бойынша: қысқа мерзімді (1 жылдан - 4 жыл аралығында), орта мерзімді (5-7 жыл аралығында), ұзақ мерзімді (8-30 аралығында) болып бөлінеді.

Мемлекеттік облигацияларға салымдар тәуекелі төмендігімен сипатталады, қарастырылып отырған кезең үшін (2020 жылдың 1-ші қазаны-2021 жылдың 31 желтоқсаны аралығы) бұл құралдардың табыстылығы 4,8\%-дан 7,19\%-ға дейін өсті. Оның себебі ЖЗҚ зейнетақы активтерін БЖЗҚ-на біріктіргенен кейін салымдардың көбі ұзақ мерзімді мемлекеттік облигацияларға салынды (МЕУКАМ-072, 084, 96, 108, 120, 132, 144, 156, 180, 240, 300 және МЕУЖКАМ-132, 144, 192) [2]. Ұзақ мерзіміді 


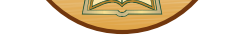

облигациялардың пайыздық мөлшері қысқа мерзімді облигацияларға қарағанда жоғары болғандықтан, олардың табыстылығы да біршама өсті. Соңғы кезеңде қысқа мерзімді облигациялар эмиссиясы қысқартылып, жылдың соңына инвестициялық портфельдің бар болғаны 8,87\% құрады. ҚҰБ қысқа мерзімді құрылымдық ноталарының эмиссиясы мүлдем тоқтатылды. Бұл құралдарға балама құрал ретінде пайыздық мөлшері жағынан жақын шет мемлекеттердің бағалы қағаздарына салынды.

- ҚР Қаржы министрлігі шығарған, ағымдағы құны 4 943,24 млрд теңгені (бүкіл портфельдің 37,36\%) құрайтын ҚР Мемлекеттік бағалы қағаздары. Теңгеге номиналданған ҚР Қаржы министрлігінің МБҚ бойынша өтеуге орташа алынған кірістілік жылына 9,3\%, ал АҚШ долларында - жылына 3,4\% құрады.

ҚР квазимемлекеттік ұйымдарының бағалы қағаздарға орналастырылған салымдар келешектегі бағыттарының бірі болып табылады. Мемлекетпен кепілдендірілген инфрақұрылымдық немесе жобалы облигациялар зейнетақы қорлары үшін мінсіз құрал болып табылады, бірақ олар инвестициялық портфельдің бар болғаны $0,13 \%$ құрайды.

Соңғы кезде қазақстандық еурооблигациялар бағасы өсіп келеді. Қазіргі кезде, көптеген батыс инвестициялық банктердің талдаушылары қазақстандық еурооблигациялар нарығында бағаның әрі қарай өсуін болжап отыр. Корпоративтік облигациялар мемлекеттік бағалы қағаздардың табыстылығынан асып түсетін, инвестициялық табыспен қамтамасыз ететін белгіленген табыстылығы бар құралдарға жатады, олардың ішінен ең өтімді құрал ретінде - еурооблигацияларға ерекше орын берген жөн. Бұл құралдардың табыстылығы қарастырылып отырған кезең үшін 7,28\%дан 8,88\%-ға дейін өскен. Табыстылығы жағынан корпоративтік облигацияларға баламалы құрал ретінде ЕДБ салымдарын алуға болады, олардың табыстылығы осы кезеңде 6,69\%-дан 8,81\%-ға дейін өскен.

- ҚР квазимемлекеттік ұйымдарының облигациялары (ағымдағы құны 1 724,49 млрд теңге (портфельдегі үлесі - 13,03\%). ҚР квазимемлекеттік ұйымдарының теңгемен номиналданған облигациялары бойынша өтеуге орташа алынған кірістілік жылына 10,8\%, АҚШ долларымен жылына 5,5\%.

Табыстылығы жағынан МБҚ-ға баламалы құрал ретінде Халықаралық қаржы ұйымдардың бағалы қағаздарын алуға болады, қарастырылып отырған кезең үшін бұл құралдардың табыстылығы 5,23\% - дан 7,31\% - ға дейін өскен. Бірақ мұндай салымдардың табыстылығы күтілетін жылдық құнсыздану деңгейінен төмен $(7,4 \%)$ болғандықтан, құнсызданудан болған залалдардың орнын да толтыра алмады.

- шетелдік мемлекеттердің мемлекеттік бағалы қағаздары 1 577,93 млрд теңге болды. Олардың портфельдегі үлесі - 11,93\%. БЖЗҚ-ның ЗА портфеліндегі есепті күндегі шетелдік мемлекеттердің МБҚ өтеуге орташа алынған кірістілік жылына 0,6\%.

- 1039,68 млрд теңгеге (7,86\%) ҚР екінші деңгейдегі банктерінің облигациялары. ҚР ЕДБ теңгеге номиналданған облигациялары бойынша өтеуге орташа алынған кірістілік есепті күнге жылына 10,0\%.

БЖЗҚ зейнетақы активтері есебінен сатып алынған қаржы құралдары номиналданған валюталар бөлінісінде қаржы құралдарының инвестициялық портфелі былайша берілген:

- Ұлттық валютадағы инвестициялар - 67,88\%, ақш долларында - 32,05\%, ресей рублінде және басқа валютада - зейнетақы активтері портфелінің 0,06\%.

ҚРҰБ алған, жыл басынан бері есептелген инвестициялық табыстың құрылымы мынадай сипатқа ие: 
- Бағалы қағаздар, оның ішінде орналастырылған салымдар және «кері репо» операциялары бойынша сыйақы түріндегі кірістер 730,36 млрд теңге;

- Бағалы қағаздарды нарықтық қайта бағалаудан түскен кірістер 191,26 млрд теңге;

- Шетел валютасын қайта бағалаудан түскен кірістер 39,53 млрд теңге;

- Сыртқы басқарудағы активтер бойынша кірістер 111,44 млрд теңге;

- Өзге де кірістер 175,25 млрд теңге.

Инвестициялық қызмет нәтижесінде, сондай-ақ, шетел валюталары бағамдарының құбылмалылығы және қаржы құралдарының нарықтық құнының өзгеруі салдарынан есептелген инвестициялық кіріс мөлшері 2021 жылдың басынан бастап 1 247,84 млрд теңге. 2021 жылдың басынан бастап салымшылардың (алушылардың) шоттарына бөлінген БЖЗҚ зейнетақы активтерінің кірістілігі инфляция 7,00\% болған кезде 9,93\% жетті. Осылайша БЖЗҚ зейнетақы активтері бойынша нақты табыстылық 2,93\% көрсетті.

Бұл ретте 2021 жылдың 1 қарашасындағы жағдай бойынша БЖЗҚ салымшылары (алушылары) үшін соңғы 12 айдағы (2020 жылдың қарашасынан 2021 жылдың қазанына дейін) зейнетақы активтерінің кірістілігі 8,90\% мөлшеріндегі инфляция кезінде 10,90\% құрады. Осылайша БЖЗҚ зейнетақы активтері бойынша соңғы 12 айдағы нақты табыстылық 2,00\% көрсетті.

Инвестициялық қызмет нәтижесінде, сондай-ақ, шетел валюталары бағамдарының құбылмалылығы және қаржы құралдарының нарықтық құнының өзгеруі салдарынан 2021 жылдың 15 наурызынан бастап 1 қарашасына дейін есептелген инвестициялық табыс мөлшері 95,70 млн теңге болды. Зейнетақы активтерінің табыстылығы - 6,47\%.

«Jusan Invest» АҚ басқаруындағы қаржы құралдарының эмитенттері көрсетілген инвестициялық портфелінің толық құрылымы БЖЗҚ сайтында жарияланған.

«Halyk Global Markets» АҚ-ның сенімгерлік басқаруындағы зейнетақы активтері 1 қарашада 1,56 млрд теңгені құрады. Портфельдің құрылымында ҚРҰБ ноттары (портфельдің 20,59\%), ЕTF пайлары (17,78\%), КР квазимемлекеттік ұйымдарының облигациялары $(16,10 \%)$, ЕДБ облигациялары $(10,00 \%)$, шетелдік эмитенттердің акциялары мен депозитарлық қолхаттары (9,85\%), кері РЕПО операциялары $(9,33 \%)$, ҚР ұйымдарының корпоративтік облигациялары (7,94\%), ХҚҰ $(7,80 \%)$ және шоттардағы ақша қаражаты $(0,60 \%)$ бар. Портфельдегі ұлттық валютадағы инвестициялар 71,82\%, АҚШ долларында $28,18 \%$.

Инвестициялық қызмет нәтижесінде, сондай-ақ, шетел валюталары бағамдарының құбылмалылығы және қаржы құралдарының нарықтық құнының өзгеруі салдарынан 15.03.2021 жылдан бастап 01.11.2021 жылға дейін есептелген инвестициялық кіріс мөлшері 74,38 млн.теңге болды. Зейнетақы активтерінің табыстылығы 6,11\% жетті.

«Halyk Global Markets» АҚ басқаруындағы қаржы құралдарының эмитенттері көрсетілген инвестициялық портфелінің нақты құрылымы БЖЗҚ сайтында жарияланған.

«BCC Invest» АҚ-ның сенімгерлік басқаруындағы зейнетақы активтері 1 қарашасындағы жағдай бойынша 1,0 млрд теңгені құрады. Олар пайларға (ЕTF индекстерге) (29,94\%), ҚР квазимемлекеттік ұйымдарының облигацияларына (19,53\%), КР ЕДБ облигацияларына (11,47\%), кері РЕПО операцияларына $(10,97 \%)$, ХҚҰ облигацияларына $(9,68 \%)$, шетелдік эмитенттердің акциялары мен депозитарлық қолхаттарына $(8,78 \%)$, ҚР резидент-эмитенттерінің корпоративтік облигацияларына $(8,22 \%)$, инвестициялық шоттардағы ақша қаражатына $(2,52 \%)$ бөлінген. Ұлттық валютадағы құралдарға портфельдің 60,00\%, АҚШ долларында 40,00\% инвестицияланған. 
Инвестициялық қызмет нәтижесінде, сондай-ақ, шетел валюталары бағамдарының құбылмалылығы және қаржы құралдарының нарықтық құнының өзгеруі салдарынан 15.03.2021 жылдан бастап 01.11.2021 жылға дейін есептелген инвестициялық кіріс мөлшері 47,80 млн.теңгені құрады. Зейнетақы активтерінің табыстылығы - 5,88\%.

«BCC Invest» АҚ басқаруындағы қаржы құралдарының эмитенттері көрсетілген инвестициялық портфелінің толық құрылымы БЖЗҚ сайтында жарияланған.

2021 жылғы 1 қарашасындағы жағдай бойынша «Сентрас Секьюритиз» АҚ сенімгерлік басқаруындағы БЖЗҚ зейнетақы активтері 572,98 млн теңгені құрады. Олар ҚР ҚМ МБҚ-ға (86,68\%), ҚР эмитенттерінің акциялары мен депозитарлық қолхаттарына $(13,31 \%)$, инвестициялық шоттардағы ақша құралдарына $(0,01 \%)$ инвестицияланды. Барлық инвестициялар ұлттық валютада жүргізілді.

Инвестициялық қызмет нәтижесінде, сондай-ақ, шетел валюталары бағамдарының құбылмалылығы және қаржы құралдарының нарықтық құнының өзгеруі салдарынан 01.04.2021 жылдан бастап 01.11.2021 жылға дейін есептелген инвестициялық кіріс мөлшері 40,69 млн.теңгені құрады. Инвестициялық қызмет және қаржы құралдарының нарықтық құнының өзгеруі нәтижесінде зейнетақы активтерінің кірістілігі 8,45\% болды.

«Сентрас Секьюритиз» АҚ басқаруындағы қаржы құралдарының эмитенттері көрсетілген инвестициялық портфелінің толық құрылымы БЖЗҚ сайтында жарияланған.

Портфелдегі ҚР эмитенттерінің корпоративтік облигациялары бойынша өтеуге орташа алынған кірістілік жылына 8,51\% құрады.

Қазіргі таңда корпоративтік облигациялар айтарлықтай тартымды құрал болып табылады. Бұл құралдарға салымдар табыстылықтың белгілі бір деңгейіне кепілдік беретін инвестициялық портфельді құруға мүмкіндік берсе, ал оның жоғарғы өтімділігі жеткілікті деңгейде нарықтық тәуекелді тиімді басқаруға мүмкіндік береді.

ЕДБ депозиттері де тіркелген табыстылығы бар құралдарға жатады, ал олардың пайыздық мөлшері қарастырылып отырған кезеңде 7,74\% тең, әдетте корпоративтік облигациялардың мөлшерінен $(8,51 \%)$ аспайды [3]. Бұл құралдар жеткілікті инвестициялық тартымдылыққа ие, банк депозиттері корпоративтік облигациялар мен вексельдерге жұмсалынған салымдардың баламасы ретінде қарастырылады, өйткені депозиттің өтімділігінің шектеулілігі, нарықтық конъюнктураның өзгерісіне жедел әрекет етуіне мүмкіндік бермейді. Одан басқа, банктер шын мәнінде инвесторлар мен инвестициялардың нақты алушылары арасындағы делдал ретінде танылады, ал ол зейнетақы активтерін орналастыру барысында жүйелі тәуекелді қосымша арттырады. Сол себепті зейнетақы активтерін орналастыру кезінде тікелей қарыз алушыларға ерекше ықылас беріледі. Тәуекел деңгейі жеткілікті түрде қалыпты болған жағдайда ғана, салымдар табыстылықтың жоғарғы деңгейін қамтамасыз ете алады.

2021 жылы зейнетақы активтерінің жалпы көлемінде депозиттердің үлесі жоғарлады, ол зейнетақы активтерінің 16,13\% құрады. ЕДБ-ға ұлттық валютада инвестициялау көлемі өсті.

Қарастырылып отырған кезеңде келесі бес екінші деңгейдегі банктерде депозиттер өтелді: «Jýsan Invest» АҚ сенімгерлік басқаруындағы зейнетақы активтері 2,55 млрд. Теңгені құрады. Оларға ҚРҰБ ноттары (портфельдің 36,24\%), Exchange Traded Funds (ETF) пайлары (22,90\%), ҚР Қаржы министрлігінің МБҚ (17,73\%) сатып алынды, инвестициялық шоттарда ақшалай қаражатта қалған активтер - 23,13\%. Портфельдің 53,99\% теңгемен, 46,01\% АҚШ долларында [4].

Акциялар ең тәуекелді салымдарға жатады, олардың табыстылығы толығымен нарық коньюнктурасына байланысты, сондықтан олардың портфельдегі үлесі төмен, бірақ та келешекте бұл құралдарға орналастырылған салымдардың тиімділігі, тіркелген 
табыстылығы бар құралдардан едәуір жоғары болуы мүмкін. Есепті кезеңде БЖЗҚ портфеліндегі ҚР эмитенттері акциялары мен депозитарлық қолхаттардың үлесі 3,36\%-дан 3,40 \%-ға дейін артты. ҚР эмитенттерінің депозитарлық қолхаттары мен акцияларының үлесінің артуы зейнетақы активтерінің жалпы көлемінің ұлғаюы нәтижесінде туындады. Акцияларға инвестиция салатын 18 компания бар, бірақ олардың тек 6 ғана активті. Есепті кезеңде БЖЗҚ зейнетақы активтерінің портфеліндегі шетелдік эмитенттердің акцияларының үлесі портфелдің $0,66 \%$ құрады.

Бүгінгі күні әлемдік қаржылық алаңдағы жағдайдың тәуекелі өте жоғары болғандықтан, инвесторлардың басым көпшілігі хеджирлеу құралы ретінде қымбат металды пайдаланып отыр. Ал ИПБ ұйымдары өз кезегінде қымбат металды инвестициялық портфелдегі қойылған заңнамаға байланысты үлесін сақтап қалуды жоспарлап отыр.

Теңгедегі деривативті нарық мүлдем жоқ деуге болады, яғни мұндай еурооблигацияларды шығаруды хеджирлеу қымбатқа түседі. Вексельдер МБҚ табыстылығынан асып түсетін табыстылықты қамтамасыз етеді, қанағаттандырарлық өтімділікке ие, жеткілікті түрде сенімді құрал болып табылады.

Активтерді орналастырудың мұндай баламалы нұсқалары тиімді механизм болып саналмайды, дегенмен тығырықтан шығу жолының бірі болып есептеледі.

Жоғарыда баяндалған талдауға сүйене отырып, зейнетақы активтеріне тән келесі ерекшеліктерді атап өткен жөн:

- Зейнетақы құралдарының бағасы, зейнетақы активтерінің портфелін құру нәтижесінде қалыптасатын инвестициялық табыстың көлемімен (нормасымен) өлшенеді;

- Тікелей құралдарға сұранысты қалыптастыру қолданыстағы заңнамалық нормаларға сүйенеді (зейнетақымен қамтамасыз етудің қоғамдық табиғатына сүйеніп мәжбүрлі жолмен);

- Зейнетақы капиталы нарығындағы сұраныс пен ұсыныс көп жағдайда мемлекетпен реттеледі;

- Қаржылық сипатына келсек зейнетақы активтері, зейнетақы капиталы нарығындағы қаржы құралдарының тәуекелінің төмендігімен, реттелетіндігімен және төменгі табыстылығымен сипатталады;

- Зейнетақы капиталы нарығының құралдарының алуан түрлілігі айтарлықтай емес, оның түрлері және мәні нақты заңмен реттеледі және нарықтық конъюнктура өзгерісіне онша ұшырамайды;

- Құралдар бағасына зейнетақы қорының инвестициялық портфелінің әртараптандыру дәрежесі, портфельді басқарушының кәсіби біліктілігі, портфельдің мазмұны бойынша реттеуші нормалардың деңгейі және зейнетақы қорының барлық портфелінің табыстылығын анықтайтын басқа да факторлар әсер етеді;

- Зейнетақы активтері мемлекеттік әлеуметтік саясатты жүзеге асыруда оның негізгі құралы болып табылады;

- Инвестициялық ресурс ретінде зейнетақы активтері ел экономикасын арзан, ұзақ мерзімді инвестициялық ресурстармен қамтамасыз етеді.

Қорытынды. Жоғарыдағы айтылғандарды ескере отырып, осы бөлім бойынша келесідей қорытынды жасауға болады:

Қазіргі жағдайда зейнетақы активтерін басқару ерекшелігі, инвестициялық портфель құрылымына белгілі бір талаптар, яғни инвестициялық портфельдегі құралдардың әртүрлі категориялары бойынша максималды үлесіне алдын-ала шектеулер қою болып табылады.

Зейнетақы активтері мемлекет тарапынан қатаң бақылауда болады: 
- Активтер бойынша (қор портфеліндегі активтердің белгілі бір түріне қойылған жоғарғы шектеулер);

- Тәуекелі бойынша (бағалы қағаздың минималды қолайлы тәуекелі);

- Меншіктік шоғырлану бойынша (жекелеген компанияның жалпы активтер көлеміндегі жоғарғы шектеулер);

- Эмитенттер бойынша (портфельдегі жекелеген компаниялардың активтер үлесіне деген жоғарғы шектеулер);

- Бағалы қағаздар түрі бойынша (бағалы қағаздардың жекелеген түрлеріне қойылған жоғарғы шектеулер).

Бұл шектеулер ішкі қаржы нарығының дамуы мен жетілуіне байланысты әлсізденуге тиісті. Активтердің нарықтық немесе бағалау құнының өзгеруінен және эмитент мүлігі құрылымының өзгеруінен, инвестициялық портфельге қойылатын талаптар бұзылған жағдайда, басқарушы компания инвестициялық портфель құрылымына қойылатын талаптарға сәйкес, активтер құрылымына түзету енгізеді.

Зейнетақы активтерін басқару механизміне келсек, активтер (акциялар) портфелін қалыптастыру барысында, волатильдігі ең төмен активтер таңдалады, яғни бастапқы мақсат болып, активтердің сақталуы, содан кейін табыстылығы есептеледі.

ИПБ ұйымдары сенімді және өте қысқа мерзімде ақша қаражатына айналатын өтімді қаржы құралдарының құрылымын қалыптастырады. ИПБ ұйымдары тәуекелі қолайлы деңгейінде тұрақты табыс алуды көздейді. Бағалы қағаздарды сатып алмас бұрын, ИПБ ұйымдары оларды баламалы қаржы құралдарымен мұқият салыстырады және дұрыс шешім қабылдайды.

Стратегияларды қолданудың тимділігі көбінесе инвестициялық қызметтің басыңқыларын анықтай алуға және мақсаттар мен негізгі қағидаларды құрамдастыра білуге байланысты. Мақсат-инвестициялардың қауіпсіздігін қамтамасыз ету.

Қазіргі жағдайда, инвестициялық портфельдегі құралдардың әрбір категориясының ең көп үлесіне алдын ала шектеулер қойылғандықтан, инвестициялық портфельдің құрылымына қойылатын талаптарды орындау, зейнетақы активтерін басқарудың ерекшелігі болып табылады.

\section{Қолданылған әдебиеттер тізімі}

1. ЕНПФ намерен выбирать БВУ для размещения депозитов посредством аукциона //thenews.kz/2021/04/17/1548287.html. 17.11.2020.

2. Доходность ЕНПФ вырастет до 6,5\% к концу 2021 года //«www.strategy 2050.kZ». 31.11.2021.

3. Планируется, что доходность по депозитам банков должна быть выше инфляции//kapital.kz/finance/29092/banki-budut-sorevnovatsya-za-dengi-enpf.html. 17.11.2021.

4. Https://www.enpf.kz/kz/indicators/pa/current.php

\section{Koldany 'lfan ədebietter ti`zi’mi`}

1 Enpf nameren vy'birat' bvu dlya razmeshheniya depozitov posredstvom aukcziona //thenews.kz/2021/04/17/1548287.html. 17.11.2020.

2 Dokhodnost enpf vy`rastet do 6,5\% k konczu 2021 goda //«www.strategy 2050.kz». 31.11.2021.

3 Planiruetsya, chto dokhodnost' po depozitam bankov dolzhna by`' vy`she inflyaczii//kapital.kz/finance/29092/banki-budut-sorevnovatsya-za-dengi-enpf.html. 17.11.2021.

4 Https://www.enpf.kz/kz/indicators/pa/current.php 


\title{
АЛЬТЕРНАТИВНЫЕ ВАРИАНТЫ РАЗМЕЩЕНИЯАКТИВОВ ЕДИНОГО НАКОПИТЕЛЬНОГО ПЕНСИОННОГО ФОНДА
}

\author{
Жантаева А. А. \\ Алматинский гуманитарно - экономический университет, город Алмать, Казахстан \\ e-mail: aigul0905@mail.ru
}

\begin{abstract}
Аннотация. В сложивщейся ситуачии особенность управления пенсионными активами состоит в том, что существуют определенные требования к структуре инвестичионного портфеля, то есть введение предварительных ограничений на верхнюю долю различных категорий инструментов в инвестиционном портфеле. Они бывают: по активам, по риску, по конщентрачии собственности, по эмитентам и по типу ценных бумаг. Поэтому в процессе формирования портфеля активов (акиий) выбираются активы с наименьшей волатильностью, т.е. первоначальной целью является сохранение активов, а затем прибыльность. В связи с этим организачиям, управляюшим инвестиционным портфелем, необходимо создать структуру ликвидных финансовых инструментов, которые могут быть конвертированы в денежные средства за очень короткий период времени и получать стабильный доход при разумном уровне риска, и принять правильное решение, тщательно сравнивая их с альтернативныли финансовыми инструментами. Эффективность таких стратегий часто зависит от способности определять приоритеты инвестиционной деятельности и сочетать цели и ключевые принципы. Цель - обеспечить безопасность инвестиций.
\end{abstract}

Ключевье слова: пенсионные активы, инвестичионный портфель, средняя доходность, риск, депозитарные расписки, еврооблигачии, фондовые облигации, структурные ноты, производные финансовые инструменты.

\section{ALTERNATIVE OPTIONS FOR THE PLACEMENT OF ASSETS OF THE UNIFIED ACCUMULATIVE PENSION FUND Zhantaeva A. A. ${ }^{1}$ Almaty University of Humanities and Economics, Almaty, Kazakhstan e-mail: aigul_0905@mail.ru}

Annotation. In this situation, the peculiarity of managing pension assets is that there are certain requirements for the structure of the investment portfolio, that is, the introduction of preliminary restrictions on the upper share of various categories of instruments in the investment portfolio. They are: by assets, by risk, by concentration of ownership, by issuer and by type of securities. Therefore, in the process of forming a portfolio of assets (shares), assets with the least volatility are selected, i.e. the initial goal is to preserve assets, then profitability. In this regard, investment portfolio managers need to create a structure of liquid financial instruments that can be converted into cash in a very short period of time and receive a stable income with a reasonable level of risk, and make the right decision, carefully comparing them with alternative financial instruments. ... The effectiveness of such strategies often depends on the ability to prioritize investment activities and combine objectives and core principles. The goal is to ensure the safety of investments.

Key words: pension assets, investment portfolio, average profitability, risk, depositary receipts, eurobonds, stock bonds, structured notes, derivative financial instruments. 